\title{
Grameen La Riba Model: A Strategy for Global Poverty Alleviation
}

\author{
Ehsan Habib Feroz \& Blake Goud ${ }^{1}$
}

\begin{abstract}
The objective of this paper is to develop and implement an Islamic microfinance model, using the Grameen group methodology, which can be used as a tool for global poverty alleviation. Our model begins with providing carefully self-selected client groups with murabaha contracts before providing musharaka finance. The murabaha financing agreement includes fixed payments each period of repayment and therefore is easier to administer and can be used to screen out potentially problematic clients who are most likely to default. Those clients who are in groups with successful repayment of the murabaha finance will have a choice between murabaha and musharaka financing in the future. Finally, we describe our implementation strategy and preparations for a pilot study in Colombo and Bibile, Sri Lanka.
\end{abstract}

JEL classifications:B10; C93; D24; F02; G21; I30; L87; O10; O16; Z10

Keywords: Islamic finance, Microfinance, Usury, Poverty, Economic Development, Equity, Socially Responsible Business, Cultural Economics, Grameen Bank, Bangladesh, Sri Lanka 


\section{Introduction}

Since Professor Muhammad Yunus and the Grameen Bank received the Nobel Peace Prize for their work in microfinance, the industry has been receiving much press, most of it positive. Microfinance, the lending of small amounts to poor borrowers without collateral, has developed rapidly, particularly in the last five years. One of the best known microfinance institutions (MFIs), the Grameen Bank in Bangladesh saw growth in loans from \$229.14 million in 2001 to \$488.41 million in 2006, an increase of $113.15 \%$ (14.4\% annually) (Grameen Bank, 2006). Despite this growth, most banks in developed, developing, and especially, less developed countries still ignore poor clients because their lack of collateral makes them more risky, and the lenders fear the poor clients will feel little obligation to repay loans.

Lending policies by state-owned banks, particularly in South Asia, have resembled grants and have not instilled a culture of repayment among many borrowers, both small and large. Credit has been allocated largely through personal or family connections, not on careful risk analysis basis to minimize the risk of default. When Dr. Yunus first began lending small amounts out of his own modest professorial salary to the poor women in rural Bangladesh, his aim was to empower the poor to start their own businesses and generate sustainable income. He did so among some of the poorest people in the world and with a conventional interest-based model in a predominantly conservative Muslim country. His success, notwithstanding the critics in Bangladesh and elsewhere, speaks to the need for providing more affordable business financing to the poor people in the world, even in situations where objections to extending financing to women on religious grounds are common.

From the humble beginnings of microfinance in Bangladesh where an economist's desire to assist a struggling community led to the development of the Grameen Bank, we believe that lessons learned in the development of Islamic (Shari'ah) banking can be applied on a micro-scale to assist in poverty reduction. The 'best practices' of microfinance can be integrated with the principles of Shari'ah to 
create a model that equitably allocates risk and return between investors and the entrepreneurs without subjecting the micro-entrepreneurs to disproportionate risks.

Islamic finance is predicated upon changing the inherently asymmetrical contractual relationship between borrowers and lenders to reduce inequity between the provider and recipient of capital in terms of risks and returns. A riba-based financial system, which is at the core of the current global financial crisis (Feroz, 2009), places disproportionate risks of repayment upon the borrower, who is obligated to repay the principal plus compounded interest, whether the business for which the funds were borrowed is successful or not.

Shari'ah scholars generally agree that musharaka is a more 'Islamic' form of financing than murabaha because it relies upon risks and profit-and-loss sharing. However, murabaha can play a transitional role in providing Shari'ah-based financial services to the poor. The use of murabaha, which shares many of the same procedures with conventional microfinance, can provide an avenue by which microfinance 'best practices' are integrated into a Shari'ah-based microfinance model.

Many developing countries rely on state-owned banks to provide financing to the poor mostly in the rural agricultural sector of the economy. Because of lax enforcement of repayment agreements and generous write-offs, many poor borrowers view a microfinance loan as more of a charitable grant than an investment requiring repayment. This problem is particularly acute in Sri Lanka since much of the posttsunami aid flows blurred the line between loans and grants. The use of murabaha, which has equal repayments like conventional microloans, allow initial focus on emphasizing that financing does indeed need to be repaid if future financing is to be available $^{2}$. Incorporating microfinance 'best practices' into a murabaha product allows the MFI to focus on the 'know your customer' approach familiar to many MFIs and also allows training to be easily incorporated. This training component is vital for the success of the musharaka product. 
Once an MFI creates a client base where repayment is expected and clients can be selected based on probability-of-repayment, a level of goodwill or trust is established to implement the musharaka product. Training of clients, particularly on basic bookkeeping, enhances the ability of clients to demonstrate that reported profits are accurate and reliable. When an MFI can trust its clients to make repayments and group members are trained well enough to keep records, it should also be able to verify its clients' reports on business profit or loss. Under these conditions, an investment-oriented MFI can offer musharaka financing to its clients. Very little work has been done using a musharaka contract, but we believe that the Grameen model provides a framework in which it can be successful, specifically in a microfinance context.

The rest of the paper is as follows. In part 2, we provide a brief overview of the literature on microfinance as it relates to poverty alleviation. Part 3 articulates the components of the Grameen La Riba model. Part 4 provides an overview of the Sri Lankan microfinance market, while part 5 describes the guidelines for implementation of the microfinance pilot program. Finally, part 6 concludes the paper and stipulates the policy implications of our proposed model.

\section{Microfinance and Poverty Alleviation}

Microfinance is one of the most popular tools employed as part of a poverty reduction strategy (Farooq, 2008). This occurred through informal governmental and multi-lateral support, direct support, and the encouragement of non-profit organizations to begin offering microfinance. This growth began in the 1990s, when organizations like UNICEF began to expand their support of MFIs. Anecdotal evidence from many programs supports the general belief that "the combination of access to microcredit and basic social services is an effective and cost-efficient approach to enable the poor to pull themselves out of poverty" (UNICEF, 1997: 18). 
This anecdotal evidence is supported by several econometric studies (see, for example, Morduch and Haley (2003)).

While microfinancing as a bridge between outright grants and traditional financing continues to grow, critics of microfinance have cast doubt upon the benefits of microfinance. These criticisms are centered on the lack of data about access to microfinance and its impact on hard-core poverty, the potential detrimental effects of high interest rates on borrowers, and a continued need to focus on education, healthcare and basic infrastructure in a holistic poverty-reduction strategy ${ }^{3}$. Proponents of microfinance claim that it 1) increases income for clients, 2) increases human development indicators (e.g., primary school attendance, healthcare, nutritional intake), and 3) offers a sustainable poverty alleviation tool because high repayment rates allow MFIs to be less reliant upon external funding. There is sufficient validity to the criticisms of microfinance that further studies are needed to gauge its efficacy. We summarize below a few studies, using data collected in three South Asian countries: India, Bangladesh, and Sri Lanka, which provide mixed evidence that microfinance is generating tangible benefits to its recipients.

Arun, Imai, and Sinha (2006) use data collected for the Small Industries Development Bank of India (SIDBI). The cross-sectional data coveres 20 MFIs and 3,320 households that are clients of these MFIs and 1,226 that are not who act as a control group. Arun, Imai and Sinha (2006) use a propensity score matching technique that compares the welfare of a household with access to microfinance with the expected welfare if the household did not have access to an MFI. They find that access to microfinance has a significant impact in terms of welfare gains. The welfare measure they use includes income, both amount and regularity, household assets, and fulfillment of basic need (e.g. food security, sanitation, and access to healthcare). The welfare impact varies based on type of access (i.e. rural or urban). Households in urban areas that are clients of an MFI are found to have higher welfare whether or not the loans are used for productive purposes like starting a business. 
In the rural areas, in contrast, only those households who receive loans for productive purposes are able to capture welfare gains from microfinance. Because microfinance can create some welfare gains by providing deposit services and consumption loans, at least in rural areas, these products should not be necessarily eliminated, particularly since the only available substitute to these loans are local money lenders (the so called, mahajans) who charge significantly higher interest rates than MFIs. In addition, deposit products are important as a way to create savings that can act as a buffer against unexpected natural Malthusian factors (such floods and famines), and also provide MFIs with a sustainable source of funds ${ }^{4}$. However, if the primary goal is creating household welfare gains, channeling funds towards financing productive purposes should be the primary focus of MFIs to reduce poverty in both rural and urban areas.

Bali, Swain, and Floro (2007) also evaluate the efficacy of microfinance with a focus beyond income poverty. Their 'vulnerability' metric is characterized by a "high degree of exposure to risks, shocks, and proneness to food insecurity that can undermine the household's survival and the development of its members' capabilities". (Bali, Swain, and Floro, 2007: 3). Their econometric study tests whether membership of a Self-Help Group (SHG) reduces household vulnerability and offers pecuniary and non-pecuniary benefits to group members. Like Arun, Imai and Sinha (2006); Bali, Swain, and Floro (2007) use data from India. The data, 858 households with SHG members and 167 without, were collected by the National Bank for Agriculture and Rural Development (NABARD) in 2000 and 2003.

Bali, Swain, and Floro (2007) first decompose their vulnerability index into three parts: income poverty, idiosyncratic risk, and aggregate risk. They find that income poverty is the greatest contributor to vulnerability and that households with SHG members have lower welfare loss from the risk of income poverty than nonSHG households. Aggregate risk and unexplained risk, which they believe includes unobservable idiosyncratic risks, make up a smaller part of the vulnerability index for 
both groups. Also, the difference between SHG and non-SHG households is lower for aggregate and unexplained risks than for income poverty.

Bali, Swain, and Floro (2007)'s analysis finds that SHG participation can make households significantly less vulnerable to poverty and food insecurity and can mitigate some of the other risks included in the vulnerability index, but to a much lesser degree. Incorporating greater risk-sharing in microfinance to reduce each household's vulnerability to risk could provide another avenue through which MFIs could contribute to reducing poverty.

Khandker (2003) studies the impact of microfinance in Bangladeshi villages where it is available and finds that it produces gains in household income and total assets, as well as producing significant spillover from individuals with access to microfinance to other members of the village ${ }^{5}$. He also finds a different impact on both MFI clients and the villagers depending upon the gender of the recipient.

Khandker (2003) uses data collected in 1991/92 and 1998/9 in Bangladesh and found that borrowing by men resulted only in greater non-food household expenditure while borrowing by women resulted in both greater food household expenditure and increased household assets. This suggests that borrowing by women rather than men creates greater benefits to the households by increasing the amount spent on food and creating greater household assets, which could be available for future income-generating activities.

In addition, the data show significant spillover effects from microfinance to other members of the village. Again, these effects are different depending upon the gender of the borrower. Loans made to men produce a positive spillover effect on average expenditure while loans to women produce a positive spillover on average non-land assets. Microfinance availability also produces significant reductions in extreme (hardcore) poverty and lower, but still significant, reductions in moderate poverty. 
Although microfinance is successful in increasing income and reducing poverty, there are many criticisms of microfinance that demonstrate a need for changes in how microfinance is practiced. Karnani (2007) argues that the focus on creating microbusinesses is not as valuable as proponents argue because many developing countries already have a sub-optimally high level of small businesses that are not able to exploit economies of scale available to larger businesses. He argues that larger businesses are able to create more employment than microfinance and this is a more effective way to reduce poverty.

Furthermore, in countries lacking good education and well developed infrastructure, microbusinesses may be able to repay their loans but do not see much benefit because these gains are captured in the interest payments to MFIs. This sentiment is echoed by Ahmed (2002) who believes that Islamic microfinance can provide greater benefits to clients through non-interest-based financing and a reliance on funds from awqaf as a substitute to expensive external funds ${ }^{6}$.

Worries about how high interest rates could harm poor borrowers provided the basis for recent criticism of Compartamos, a MFI in Mexico that charges interest rates in excess of 100\% per year (CGAP, 2007: 5). Compartamos raised interest rates to these high levels during the Mexican currency crisis in 1995 when the peso was devalued. The organization (at that time it was non-profit) chose to leave interest rates at this higher level to generate profits that could be used to fund rapid expansion.

In 2000, Campartamos converted into a for-profit MFI and now has over 700,000 borrowers. The return-on-equity of the MFI is significantly than those seen in the Mexican banking industry and the microfinance industry despite higher administrative costs. Compartamos makes significantly smaller loans than most MFIs. In 2007, Compartamos decided to make an initial public offering (IPO), which generated significant profits for investors, mostly other non-profit organizations ${ }^{7}$. 
The high profits made by investors in the MFI and the IPO have lead to criticism that these profits were made by charging poor borrowers usurious interest rates. Although most of the investment gains seen by investors were the result of external factors like an absence of comparable securities (the IPO was 23 times oversubscribed) and the MFI's bank license (a large intangible asset), some of the investment gains were a reflection of the high profit rate of the company. However, the MFIs' significant reinvestment of profits meant that most of these profits were not flowing to private investors, but rather allowing the MFI to increase the number of borrowers it could serve.

Although most of the profits were used to provide credit to other people living in poverty, there is still a significant distributional inefficiency involved: existing clients are being overcharged in order to fund loans to new borrowers who would otherwise not have access to microfinance. This trade-off between current clients' welfare and the benefits gained from an expansion of lending activities is a difficult one, particularly for non-profit organizations who do not want to be seen as generating high profits from loans to poor borrowers, regardless of whether these profits are reinvested in expanding access to microfinance.

The success of Compartamos in simultaneously attracting new borrowers and maintaining high rates of repayment while making enough profits to fund rapid expansion suggests that microbusinesses are able to capture high returns to capital. In Sri Lanka, de Mel, Woodruff, and McKenzie (2007a) find that this is indeed the case. They randomly provided some microentrepreneurs with LKR 10,000 or 20,000 (roughly $\$ 100$ or $\$ 200$ ) and then compared the returns on capital in these microbusinesses against the control group, which did not receive additional capital. They found that, on average, microbusinesses experienced a return to capital of $5.7 \%$ per month (at least $68 \%$ annually if the profits are used by the household and not reinvested).

Although these returns are significantly higher than the interest rates charged by most MFIs (excluding Compartamos), these returns vary across gender of the 
microentrepreneur (de Mel, Woodruff, and McKenzie, 2007b). Male entrepreneurs have high average returns while female entrepreneurs report insignificantly positive or negative returns. The reasons as to why women earn lower returns than men are unclear, but de Mel, Woodruff, and McKenzie (2007c) do not find that female entrepreneurs have lower ability or use more of the microfinancing on non-business household expenses. Part of the difference could be due to men and women working in different industries, but de Mel, Woodruff, and McKenzie (2007c) document intraindustry differences in returns between men and women.

In summary, the literature on microfinance indicates that when microfinancing is available, the profitability of microbusinesses is often higher than the interest rates charged by conventional MFIs. This profitability from microfinance loans for businesses leads to reductions in poverty and vulnerability among clients and their households. However, there is mixed evidence on whether the benefits are greater depending upon the gender of the client.

The benefits from providing microfinance in poor communities create significant positive spillover to other members of the community who do not receive microfinance loans. Concern over usurious interest rates charged to clients, irrespective of whether or not they see a sustainable level of income generation, provides an opportunity for a new type of microfinance based on Islamic ethical guidelines about the relationship between investors (MFIs) and entrepreneurs (clients).

\section{The Grameen La Riba Model}

The Grameen Bank in Bangladesh and other MFIs throughout the world have found the human portfolio approach (an innovative application of the portfolio theory of finance) or group lending methodology to be very effective in ensuring high repayment rates, that allow MFIs to charge lower interest rates and still become profitable (Feroz, 2007). In a group lending strategy, an MFI will provide loans to 
groups of five borrowers together and each member shares joint responsibility (risks) with all of the other group members. This human portfolio approach is used, in part, because poor borrowers (clients) do not typically have physical collateral to guarantee their own loans, and hence joint group responsibility (essentially, a pooling of risky 'clients' instead of pooling risky debt 'securities' as it is practiced in corporate finance) allows them to use 'social collateral' instead as their guarantee. If a member of the group is not able to make payments, the other members of the group are not eligible for additional funding until all members of the group are current on their repayments. Members can either repay the late payments of the delinquent member who is not current or apply social pressure to the member who is lagging behind on repayments.

In addition to group lending, Armendariz de Aghion and Morduch (2005) find that dynamic incentives (e.g., making future loan eligibility contingent upon current loan repayment on-time), frequent repayment installations, and public repayment lead to higher repayment rates. These incentive mechanisms are included in our model to ensure higher probability that the pilot study planned for in Sri Lanka will be successful.

Our financing model is based on the murabaha and musharaka contracts frequently used by Islamic banks. In the former, the MFI purchases goods requested by the client from vendors and resells them to the client with a pre-agreed upon markup and receives payments spread over an agreed-upon time (usually 52 weeks or less). In the latter, the MFI and client sign an agreement specifying the business conducted by the client, the profit-sharing ratios, and the buy-out schedule. Upon signing, the MFI provides the client with money to expand the client's business and they share profits and losses until the agreement ends with the client gradually buying the MFI's share of the business. The group structure and financing products will be discussed in greater detail in the following section.

\section{Group Lending Methodology}


In microfinance environments relying on groups, the group size typically ranges from five to fifteen. The Grameen Bank and other MFIs use groups of five women each, which is what we will use as well. The success of the microfinance program, measured by repayment rates and number of participants able to expand their businesses, will be dependent upon the ability of group members to effectively sanction the members who 'strategically default' and support those that run into financial difficulty if their business is temporarily struggling ${ }^{8}$. One important determinant of group success is whether the group members can accurately discern which fellow borrowers will repay on time or whether they will claim hardship and strategically default to avoid the burden of repayment. In addition, group members will be less likely to strategically default if the group is able to effectively discipline its members for late payments.

Most MFIs only work with self-selected groups on the assumption that group members will only select fellow group members who they believe have the highest probability of success, will repay on time and who they believe will respond to social sanctions if they are late in repayments. Another factor not as frequently mentioned, but possibly an important factor for group selection, is that members will be drawn to select members who are known to be generous. In case a member falls behind on payments because their business is unsuccessful or they are hit with a personal hardship, they would prefer to have fellow group members who will assist them in making repayments on time.

\section{Murabaha (Cost-plus resale with deferred repayment)}

When borrowers form groups and approach the MFI for financing, they will not immediately be eligible for profit-and-loss sharing musharaka-based products, but will instead be offered a murabaha-based product that has fixed repayment amounts across the length of the financing. This product is used with new groups to establish a business relationship between the MFI and the clients. The murabaha product will function much like it does in Islamic banks around the world, with the only difference 
being that it will be distributed to only two members at first. If repayment is made on time, then two other members will receive financing and, if repayments continue to be made on-time, the final member of the group (who is also the group leader) will receive financing.

The financing agreement for each group will operate as follows: the client will submit a request for items needed to operate the microbusiness to the MFI who will then determine the cost of the goods requested ${ }^{9}$. The MFI and the client will then agree upon the profit margin for the resale of the goods to the client and the client will be presented with the cost of the requested goods. The MFI and client will sign an agreement specifying:

i) description and cost of the goods requested,

ii) profit margin for the resale of goods from the MFI to the client,

iii) total repayment amount, frequency, and number of repayments, repayment dates and amounts, and

iv) place where the goods will be delivered to the client.

If there is a late fee corresponding to the costs of collecting the repayments (e.g., additional MFI staff time spent following up with the client), these would be included in the original agreement. However, for the pilot study we will be undertaking, a late fee will not be charged. Instead, late repayments will subject the entire group to a cut-off from additional funding until the late payments are made current. If we find that the costs from late payments are significant and the denial of future credit does not provide enough incentive for on-time repayment, we may institute a late payment fee.

When the goods are delivered to the client, the client will retain the right to reject goods that are damaged or not agreed upon in the initial agreement without penalty. The client and MFI will sign a document describing why the goods were rejected and the date and place where new goods will be delivered and any changes to the cost of the goods requested. 
After the goods are delivered to the client, there will be weekly group meetings where repayments are made publicly, both to allow group members to observe whether their fellow group members are current on their repayments, as well as to verify that the MFI staff member collecting repayments reports to MFI honestly (and does not embezzle part or all of it). During the meetings, clients will be able to ask MFI staff members for advice on running their businesses and will be encouraged to discuss lessons learned in the previous week's business operations with other members of the group.

Our focus with the murabaha financing will be to ensure that clients know that on-time repayment is expected and to help the MFI collect knowledge about groups that it can use in the future when considering whether to provide future financing, either using murabaha or musharaka. The murabaha financing is similar to a microloan, but has a few key differences that provide an advantage to conventional microfinance. The first is that instead of providing a loan of cash for repayment in the future with interest, the murabaha product is based on a purchase and resale where the markup (a profit on a sale) is agreed upon in advance and does not depend upon the length of financing or on-time repayment ${ }^{10}$. The other difference is that by providing goods instead of money, the MFI will know what is being financed, and will only need to ensure that the goods are used for business purposes (e.g. by visiting the microbusiness throughout the week) instead of consumption.

\section{Musharaka}

If a group successfully finishes a cycle of business with murabaha financing, then the MFI will decide whether to offer additional financing and whether this could include musharaka financing. If a group becomes eligible for musharaka financing, then the MFI will work with the client to describe the types of business activity being undertaken by each member of the group. If the businesses are deemed to have a high likelihood of profitability in the future if an additional investment is made, then 
the group will be provided with additional finance. The agreement between the MFI and the group will specify the following:

i) type of business being operated,

ii) amount of investment,

iii) profit-and-loss sharing ratio, and

iv) investment buy-out schedule.

The restriction placed on the types of business are included to ensure that the MFI knows what the microentrepreneur is planning on doing with the investment and to ensure that the funds are used for a business purpose and not for consumption ${ }^{11}$. The mix between business and consumption loans in the extant microfinance industry has made it difficult, if not impossible, to accurately gauge whether microfinance is meeting its promise to act as an effective tool for poverty alleviation.

The investment buy-out component of our musharaka contract is one of the most important features for creating sustainability and allowing for its expansion. If we were using a typical musharaka product, the MFI would make an investment in the microbusiness and then realize a stream of profits or losses in the future. The MFI would, however, continue to control a sizable share of the business without any ability to recover the investment to use for other worthy ventures. The MFI would instead be forced to use profits (if any) or seek additional capital to expand its operations. The microentrepreneurs also would likely avoid musharaka if it meant that they would be responsible for paying a share of their profits to the MFI each week with no end date in sight. Our model provides a happy medium between the MFI recovering its initial investment plus (or minus) the actual profit (loss) of the business, while freeing the entrepreneur to receive a growing share of the microbusiness' profits as it buys out the MFI's share of the business. 
Table 1: Musharaka Financing Example

\begin{tabular}{|cccccc|cc|}
\hline Week & $\begin{array}{c}\text { MFI } \\
\text { outstanding } \\
\text { investment }\end{array}$ & $\begin{array}{c}\text { Client } \\
\text { ownership }\end{array}$ & $\begin{array}{c}\text { MFI Profit } \\
\text { and loss } \\
\text { sharing ratio }\end{array}$ & Profit & $\begin{array}{c}\text { Total } \\
\text { Payment }\end{array}$ & $\begin{array}{c}\text { Client } \\
\text { Profit-share }\end{array}$ & $\begin{array}{c}\text { MFI Profit- } \\
\text { share }\end{array}$ \\
\hline 0 & $\$ 200.00$ & $0 \%$ & $75.0 \%$ & $\$ 8.00$ & & & $\$ 6.00$ \\
1 & $\$ 180.00$ & $10 \%$ & $67.5 \%$ & $\$ 8.00$ & $\$ 26.00$ & $\$ 2.00$ & $\$ 0.00$ \\
2 & $\$ 160.00$ & $20 \%$ & $60.0 \%$ & $\$ 0.00$ & $\$ 20.00$ & $\$ 0.00$ & $\$ 4.80$ \\
3 & $\$ 140.00$ & $30 \%$ & $52.5 \%$ & $\$ 8.00$ & $\$ 24.80$ & $\$ 3.20$ & $\$ 4.20$ \\
4 & $\$ 120.00$ & $40 \%$ & $45.0 \%$ & $\$ 8.00$ & $\$ 24.20$ & $\$ 3.80$ & $\$ 3.60$ \\
5 & $\$ 100.00$ & $50 \%$ & $37.5 \%$ & $\$ 8.00$ & $\$ 23.60$ & $\$ 4.40$ & $-\$ 0.75$ \\
6 & $\$ 80.00$ & $60 \%$ & $30.0 \%$ & $-\$ 2.00$ & $\$ 19.25$ & $-\$ 1.25$ & $\$ 2.40$ \\
7 & $\$ 60.00$ & $70 \%$ & $22.5 \%$ & $\$ 8.00$ & $\$ 22.40$ & $\$ 5.60$ & $\$ 1.80$ \\
8 & $\$ 40.00$ & $80 \%$ & $15.0 \%$ & $\$ 8.00$ & $\$ 21.80$ & $\$ 6.20$ & $\$ 1.20$ \\
9 & $\$ 20.00$ & $90 \%$ & $7.5 \%$ & $\$ 8.00$ & $\$ 21.20$ & $\$ 6.80$ & $\$ 0.60$ \\
\hline 10 & $\$ 0.00$ & $100 \%$ & $0.0 \%$ & $\$ 8.00$ & $\$ 20.60$ & $\$ 7.40$ & $\$ 23.85$ \\
\hline
\end{tabular}

Number of payments $\quad 10$

Initial profit-sharing ratio (\% to $\mathrm{MFI}) \quad 75 \%$

MFI profit rate $\quad 11.9 \%$

Client profit rate $\quad 19.1 \%$

In Table 1, the MFI provides the client with a \$200 investment in a business and the client begins operating or expands his (her) business with the additional capital. The client and MFI agree upon an initial profit-sharing ratio of $75 \%$ to the MFI and 25\% to the client and a buy-out period of 10 weeks. Over the first week, the business generates $\$ 8$ in profits. At the first group meeting, the client announces his (her) profits to the microfinance group and he (she) makes the first investment buyout of $\$ 20$ to the MFI plus the profit sharing amount of $\$ 6$ (75\% of $\$ 8$ ). At the end of the meeting, the client now owns $10 \%$ of the investment amount, and therefore the profitsharing ratio will fall by $10 \%$ to $67.5 \%$ for the MFI and $32.5 \%$ for the client.

One feature of the musharaka illustrated by the model is that profits and losses are shared according to the pre-agreed ratio. As Table 1 shows, in week 6 the client had a loss of $\$ 2$. According to the profit-sharing ratio in week 6 , the profit-andloss sharing ratio is $30 \%$ for the MFI and $70 \%$ for the client. The client would make 
the buy-out payment of $\$ 20$ less the MFI's share of the loss, $\$ 0.75$ for a total payment of $\$ 19.25$. After the initial investment has been completely bought out by the client, the MFI will decide whether to offer additional financing, restarting the process again.

The main problem created by the musharaka model is the asymmetric informational relationship between the principal (bank) and the agent (client). The success of a musharaka contract depends upon accurate reporting of profit and loss by the client that cannot be easily verified by the MFI (one reason most Islamic banks have not offered musharaka products, so far). It is this informational asymmetry that poses the greatest challenge for operating the musharaka product. In order to correct this asymmetry, we will require the clients to keep basic records on the business' activities, supplemented by occasional unannounced audits by bank auditors. This will be facilitated through training and mandatory record-keeping for one cycle of murabaha financing. However, during the murabaha financing, we will not require that the records are shared with us, except to the extent necessary for the training process. A study by de Mel, McKenzie, and Woodruff (2007a) found that many entrepreneurs continued to keep records of the business activities even after the study's conclusion, with 71 percent indicating they planned on maintaining their ledgers, and 52 percent actually doing so after one month.

We do not expect all groups of clients to desire musharaka-based financing. We believe that those that do will agree to the necessary record (book) keeping and their audits by bank auditors. In order to induce this willingness, we may offer larger financing for the musharaka product than is available, even for experienced clients, through the murabaha product. Additional socio-economic culture specific incentives may be devised and implemented in the future based on the reported profitability of clients' businesses using musharaka compared with rates seen in other empirical studies.

\section{The Sri Lankan Microfinance Market}


Sri Lanka is a country with 20 million people and one of the highest per capita income levels in Asia. The GDP per capita in 2007 was \$1,558 at current exchange rates. Despite this high per capita income, the country has a significant disparity between rich and poor and between rural, where 88 percent of country's poor live, and urban areas, where poverty rates are lower. The poverty rate has also remained fairly static over the previous 15 years, with only a 3 percent reduction between 1991 and 2002 (CGAP, 2006: 3).

The historically large role played by the government in the economy shapes the current distribution of MFIs among institutional types ${ }^{12}$ : over 50 percent of loans and over 45 percent of deposits are provided by government organizations, either Rural Development Banks (RDBs) or Samurdhis. The Samurdhi ('Prosperity') Program was started in 1994 to reduce poverty and provide other social programs. One of these programs is microfinance banks, regulated by a dedicated Ministry of Samurdhis. As of December 2004, there were 1,036 Samurdhi banks with 5 million depositors and 500,000 microloans outstanding. The RDBs, regulated by the Ministry of Cooperatives and the Samurdhis have seen their deposits and loans increase in line with a reduction in the share of the cooperatives.

On the private sector side, there are very few commercial banks involved with microfinance. Hatton National Bank is the most involved but serves only 12,500 borrowers. In addition to the traditional reasons for commercial banks to avoid poor clients, there is very little consistency in regulation of microfinance activities. Commercial banks and registered finance companies are regulated by the Central Bank of Sri Lanka, while other MFIs with different structures are regulated by a slew of other regulatory bodies.

The most prevalent form of organization of MFIs in Sri Lanka are cooperatives. There are over 1,500 Cooperative Rural Banks, 7,400 Thrift Credit Cooperative Societies operated by SANASA (a Sri Lankan apex organization) and many local cooperatives. The cooperatives, regulated by the Ministry of 
Cooperatives, are allowed to accept deposits from anyone, but make loans only to their members. Although the share of cooperatives in the total microfinance market has fallen, cooperatives operate as one of the largest forms of organization in the country.

Unlike many other countries, Sri Lanka does not have a large share of MFIs organized as non-profit organizations. There are a few large non-profit organizations like the Sarvodaya Economic Enterprise Development Services (SEEDS), which has an outstanding loan portfolio of LKR 3.45 billion (\$31.75 million). The share of nonprofits is less than $10 \%$ in number and volume of deposits and loan portfolio outstanding (see Table 2). One of the factors limiting non-profit activity in microfinance is that they are prohibited from taking deposits, although many do and enforcement activities against non-profits that take deposits are infrequent. Despite the prevalence of deposit taking by non-profits, the lack of regulatory coordination between different ministries has led to these organizations being focused on the loan side and this forces them to rely more upon external financing because the supply of depositors' money is limited by the rules against non-profit organizations taking deposits. 
Table 2: Institutional Types of Microfinance Providers in Sri Lanka

\begin{tabular}{|l|c|c|c|c|c|c|}
\hline \multirow{2}{*}{} & \multicolumn{3}{|c|}{ Deposits } & \multicolumn{2}{c|}{ Loans } \\
\cline { 2 - 7 } & $\begin{array}{c}\text { Number of } \\
\text { Accounts } \\
(\%)\end{array}$ & $\begin{array}{c}\text { Volume of } \\
\text { Deposits } \\
(\%)\end{array}$ & $\begin{array}{c}\text { Volume of } \\
\text { Deposits } \\
(\text { '000 LKR) }\end{array}$ & $\begin{array}{c}\text { Number } \\
\text { of Loans } \\
(\%)\end{array}$ & $\begin{array}{c}\text { Loan } \\
\text { Portfolio } \\
\text { Outstanding } \\
(\%)\end{array}$ & $\begin{array}{c}\text { Loan } \\
\text { Portfolio } \\
\text { Outstanding } \\
(\text { '000 LKR) }\end{array}$ \\
\hline $\begin{array}{l}\text { Development } \\
\text { Banks }\end{array}$ & $16 \%$ & $26 \%$ & $10,240,920$ & $34 \%$ & $52 \%$ & $12,909,525$ \\
$\begin{array}{l}\text { Cooperative Rural } \\
\text { Banks }\end{array}$ & $42 \%$ & $46 \%$ & $22,276,954$ & $27 \%$ & $28 \%$ & $8,144,916$ \\
NGOs & $8 \%$ & $4 \%$ & $2,083,931$ & $17 \%$ & $7 \%$ & $2,139,695$ \\
$\begin{array}{l}\text { Samurdhi } \\
\text { SANASA } \\
\text { Development }\end{array}$ & $34 \%$ & $24 \%$ & $11,761,000$ & $21 \%$ & $13 \%$ & $3,692,000$ \\
Bank & N/A & N/A & $2,309,506$ & N/A & N/A & $2,069,080$ \\
\hline
\end{tabular}

Source: Table $3 \& 4$ from CGAP (2006) from 2005 survey of Sri Lankan MFIs

Although the microfinance industry is well established in terms of coverage, several areas would benefit from further development. New legislation, the Micro Finance Institutions Act, which would centralize regulation of MFIs that are currently dispersed among several government agencies, is pending approval by the Sri Lankan legislature. The predominance of government providers of microfinance has resulted in an inefficient system where interest rates charged are not sufficient to cover costs and repayment rates are significantly lower than non-governmental MFIs in other countries. There are also few options for those who eschew interest-based financing.

The international non-governmental organization, Muslim Aid in Sri Lanka recently launched an Islamic microfinance pilot project using Islamic finance products in an urban area, Slave Island (also known as Kompannaweedia), north of Colombo. Working with two local organizations, the Kompannaweedia Mosque Federation and the Malay Association, and Amana Investments, Ltd., an Islamic financial institution, they began by providing murabaha financing to 40 people. The financing amount (depending upon need) ranges from LKR 6,000 to 150,000 (roughly \$56 to 1389 at current exchange rates of LKR 108 per US\$). The clients were selected in consultation with the Kompannaweedia Mosque Federation and the 
organizations provide clients with training in addition to financing. Because the pilot was launched recently, there is not yet data on its success.

\section{Implementation Strategy}

The model described in this paper is freely available for implementation by any bank, MFI, and governmental and non-profit organizations dedicated to poverty alleviation. Initially, the model will be tested in two areas in Sri Lanka: Colombo and Bibile. Colombo is the commercial capital of the country, while Bibile is a town in one of the least densely populated areas of the country.

The pilot study will be operated by the One Ummah Foundation, a US 501(c) (3) non- profit charitable organization working to eliminate child labor by breaking the cycle of illiteracy and poverty in underdeveloped countries. Most of the previous work of the One Ummah Foundation focused on providing school uniforms, textbooks, and funds for refurbishment of schools. In addition, the Foundation actively provides assistance to needy families so their children could enroll in school. One Ummah believes that providing microfinance that lifts families' incomes will reduce economic pressures that often lead to children entering the workforce instead of school. The Foundation works with people of all faiths. During the implementation phase, we will use more generic terms for products like cost-plus financing and profit-and-loss sharing investment, rather than murabaha and musharaka.

One of the strengths of the One Ummah Foundation for the purposes of carrying out an equity-based microfinance pilot study is that it works through a diverse group of highly trusted partner organizations in several countries concentrated in the South Asia. These partner organizations are actively involved in many facets of community members' lives and One Ummah Foundation provides funding to these organizations for specific projects furthering the Foundation's mission. This position allows the Foundation to maximize its resources without creating additional 
administrative costs and by leveraging its partner organizations' connections within the community to operate more efficiently. These collaborative relationships build capacity for this type of microfinance among people living in the communities where the programs operate.

The pilot program, as mentioned above, will be carried out in two areas of Sri Lanka and will be administered by two community-based organizations in Sri Lanka. The first organization is Al Muslimaath, a women's organization based in Colombo, Sri Lanka, which is led by a retired ophthalmologist. The second organization is the Baithul Khair Foundation, which operates in Bibile, Sri Lanka and is headed by a banker working in Colombo, Sri Lanka. These organizations will have the flexibility to modify certain aspects of the program depending upon on-the-ground experiences, as long as they notify One Ummah beforehand. The structure of the program will be based upon the model described in the preceding sections of this paper. The size, length, payment schedule, profit markup and profit-sharing ratios used in the pilot will be set by the One Ummah Foundation.

\section{Phase One: Murabaha, Cost-Plus Resale Financing}

Initially, the pilot program will begin with two self-selected groups of five women each, with up to LKR 30,000 (about \$275) in initial financing per group member. As the methodology of the model described above, each group will be provided with financing in stages. The group first elects one member as the leader of the group. The group leader is the last one to receive financing and, therefore, has an incentive to monitor the other members' use of the financed goods.

The first two members of the group meet with the people overseeing the pilot project and determine what goods they need to begin operating a micro-business or expand their already existing business. Once the list of required goods is created for both members of each group, we determine the prices of the necessary goods, combining orders together across clients and groups to reap discounts of buying larger quantities where possible. Once the prices of the goods needed by the clients 
are set, there is another meeting between the client and us where the repayment terms are agreed upon and where the list of goods and prices are set.

During the pilot phase, we are aiming for a break-even point, assuming zero cost of capital (funds will be raised from donors with no expectation of repayment), an inflation rate of $10 \%$ (IMF staff estimates for the country range from $11.0-11.5$ percent for 2008 (IMF, 2007: 227), and a repayment rate of $85 \%$. Given these assumptions and a 6-month repayment period with repayments made weekly, the markup we need to charge to reach break-even point is $20 \%{ }^{13}$. For comparison, the six months Sri Lankan Interbank Offering Rate, the interest rate at which Sri Lankan commercial banks lend to one another, averaged 12.83\% during 2006 and in the past month (January 30 to February 29, 2008) averaged 19.33\%. Although the markup is not linked to SLIBOR (or any other interest rate), the comparison with the six-month SLIBOR provides a benchmark that the cost of financing for interest-based products with a similar length is not excessive, nor is it heavily subsidized.

After we reach agreement with the client about the total financing amount, repayment terms including the markup, the list of goods and the prices at which they are available, and the delivery schedule, we will purchase the goods requested by the clients and resell them to the client with repayment deferred. The agreement with the client will specify the markup on the purchase and resale of the requested goods. Upon delivery, the exact price we paid and the resulting markup amount will be revealed to the client. If the goods are not what the client requested, he (she) has the option of refusing delivery without penalty. At this stage, we will provide each group member with a notebook to keep records about expenses, revenues and income taken by the client, but will not require that the client share these with us. We will also provide basic training so that the client knows how to keep accurate records. This will be encouraged but not mandatory unless the clients envision future use of a profit-and-loss sharing agreement (musharaka).

When the first two group members receive the goods they requested, all five members of the group will meet at least once a week with us. At these meetings, the 
group members who have received financing make their repayments and the repayments are recorded with all group members present. This provides a dual incentive for honest repayments that will become more important as we move beyond the pilot phase. It will provide a way for the other group members to know whether the other group members are making on-time repayments and will also provide a check on any potential fraud by the person collecting the repayments (e.g. if they were collecting full repayments and only reporting that three-quarters' payment was made, keeping the remaining one-fourth for themselves).

If the first two group members make the repayments on time for six consecutive weeks, the next two group members will meet with us and the same process will occur as did with the first two group members. Repayment meetings continue to occur weekly. After the first four members receive financing, if they are able to make on-time repayments for another six consecutive weeks, then the group leader will receive financing.

When all of the members have received financing, they continue to attend the weekly repayment meetings, where in addition to making their repayments, the group members are able to interact together to share insights on running their businesses. During the repayment process, we do anticipate some percentage of the clients receiving financing will be unable to make timely repayments because their business is not performing as well as expected. In this case, the other group members will be informed that unless the defaulting member brings his (her) account up to date or the group members bring his (her) repayments up to date, no additional money will be available to the group. One aspect of this group joint responsibility is that there is no joint liability (legally) for other members' loans. The greatest penalty that can be imposed on group members whose fellow members do not make on-time payments is a denial of access to future financing.

There are two outcomes possible in a group where one (or more) members are behind on their payments: either the group works its way back into compliance or the other group members finish their repayments and the group disbands. In the 
former case, either the member who misses a payment pays the missed payment (along with the next payment) at the next repayment meeting, or another member will cover the missed payment, with an understanding that the member who missed the payment will repay when he (she) is able to do so. The latter option is basically qard hasan, a loan between members without interest.

The denial of financing to the entire group provides them with incentive to make sure fellow group members are honest and is one way in which we can use 'social collateral' as a leverage. If the members of the group provide the qard (loan) to a fellow member, that sends a strong signal that the other members believe the missed payment was due to a temporary hardship and does not amount to a strategic default. If a member misses a payment and no group members provide a loan, either the other members do not have the money available or they believe the missed payment is the result of a business failure that is not temporary or is a strategic default.

The actual defaulting member will also lose financing and will only be eligible for future financing if we find that his (her) default was not intentional and a group agrees to allow him (her) to join. This structure is designed to take maximum advantage of the 'social collateral' (their knowledge about other client's personality, likelihood of success and other information that a client might want to keep hidden from a financial institution) of clients. We believe that group members who allow another member to default should face sanctions, but not nearly as severe sanctions as the member who defaults. In addition, we believe that the intra-group qard hasan could play a vital role as a signal about the reason for a missed payment.

\section{Phase Two: Musharaka, Profit and Loss Sharing Equity Financing}

One of the important outcomes we hope to see in the groups formed for Phase One is that they focus on expanding their business to raise their own incomes, and eventually becoming small businesses that are able to provide an employment opportunity for more than just their owner. This end-point is one of the crucial goals 
of microfinance. During Phase One, most of the participating micro-businesses will hopefully become more stable and less dependent upon the MFI's resources. Groups that reach the point where they are good candidates for Phase Two (musharaka) will be selected based on repayment history in Phase One, and our assessment for the potential for success of each group member. The rest of the steps to follow are similar to those in Phase One.

\section{Conclusions and Policy Implications}

Microfinance can be a powerful tool for a poverty alleviation strategy, but the experiences of MFIs in 32 years since Dr. Yunus began lending small amounts in Chittagong, Bangladesh have demonstrated that microfinance is not a panacea to poverty and should be implemented alongside complementary development programs. A holistic approach to development that emphasizes the provision of education, health care, basic infrastructure, ownership empowerment, and participatory governance can enhance the effectiveness of microfinance.

The conventional microfinance industry has created access to the financial system for millions of clients who were previously excluded, often because they were poor, or did not have physical collateral to guarantee the loan. Microfinance provides finance to these people, many of whom have used microfinance to increase their income. This success is not without criticism, however, particularly the use of debtand riba-based financing. Creating debt among people with few assets beyond their unskilled or low skill human capital (labor) and shouldering them with high interest payments (up to 100 percent annually as with Compartemos) may not be sustainable if borrowers do not earn enough to repay principal plus interest and still have enough income to provide for their families.

This problem with conventional microfinance, as well as little evidence for clients graduating from microfinance, leads to a search for better methods of providing business financing which can be filled using products developed by the 
Islamic financial industry to comply with the prohibition of riba and the concern for fairness and justice between parties in business enumerated in the Qur'an and the Sunna. The use of murabaha provides a way to train clients on recordkeeping, screen out clients who do not repay financing, and find those best able to succeed with musharaka financing while incorporating microfinance 'best practices'. Musharaka financing, which we believe is the essence of Shari'ah based financing, provides a way for an MFI to equitably share its profit and loss with its clients. Profit sharing does not have an upper limit on its profitability like riba-based financing. It also provides poor clients insulation from some of the costs of business failure and will shift some of the risks from poor clients to an MFI which is better able to diversify its risks.

The future for Shari'ah-based microfinance is promising if it can successfully integrate current microfinance 'best practices.' Muslims and non-Muslims (like the first client of the Islami Bank of Bangladesh who is a Hindu) will support the Shari' ah-based microfinance but, like Islamic macrofinance, this support will depend on whether the products are at least as effective and cost-competitive as the conventional alternative. The goal of our Grameen La Riba model is not to provide just another form of microfinance that avoids interest-based finance for devout Muslims at very high costs. We posit that the fundamentals of the classical Shari'ah concerning: (i) equitable risk and return sharing between the lender (bank) and the borrower (client) and (ii) helping the poor especially, the 'poorest of the poor' to be self-sustaining, provide the necessary foundation for an Islamic microfinance model that is better suited to help the poor increase their sustainable income and eventually escape poverty.

Indeed, we believe that the Grameen La Riba model could very well be the basis for Islamic financing both at the micro and the macro levels. At present, Islamic financing largely benefits the relatively wealthy clients who pose rather low to moderate risks in terms of loan recoverability. Certainly, the lure of the major global money center banks in offering the so called, 'Islamic windows' and other exotic 
banking services, mostly stems from the perceived deep pockets of relatively wealthy Muslim clients. To date, very few Islamic banks and financial institutions have extended microcredits to the 'poorest of the poor' even though some of them have provided extensive social services through subsidized hospitals, mostly free schools, and orphanages. It is imperative for the Islamic banks and financial institutions to revisit their Shari'ah covenant in substantive terms, not just as a formality, and reassess their strategies in terms of their larger social responsibility of local and global poverty alleviation. As the Grameen Bank has amply demonstrated, the poor people deserve credit and could very well be just as credit-worthy, if not more, than the traditional clients of Islamic and non-Islamic banks. The Grameen La Riba model provides an opportunity for both Islamic and non-Islamic banks alike to reassess their strategies in terms of poverty alleviation, and socially responsible business. It is time to stop sermonizing the global poor (estimated at one billion) by the policy makers in the public and private sectors, and instead consider the poor as rational vicegerents of Allah (albeit some might be on the verge of 'decaying Jesus' in the words of Late Mother Teresa), who can take care of themselves, only if they are provided with appropriate economic access (including finance) and equitable opportunities for social mobility. 


\section{References}

Ahmed, Habib. 2002. "Financing Microenterprises: An Analytical Study of Islamic MFIs," Islamic Economic Studies, 9(2).

Armendáriz de Aghion, Beatriz and Jonathan Morduch. 2005. The economics of Microfinance. Cambridge: MIT Press.

Arun, Thankom, Katsushi Imai and Frances Sinha. 2006. "Does Microfinance Reduce Poverty in India? Propensity Score Matching based on National-level Household Data," Institute for Development Policy and Management, University of Manchester, Working Paper Series, No. 17.

Bali Swain, Ranjula and Maria Floro. 2007. "Effects of microfinance on vulnerability, poverty and risk in low income households," Uppsala University Working Paper Series, 2007:31, December 2007.

Boudreaux, Karol and Tyler Cowen. 2008. "The micromagic of microcredit," The Wilson Quarterly, Winter 2008, 27-31.

CGAP. 2006. Country Level Effectiveness and Accountability Review (CLEAR). Washington, DC: CGAP.

CGAP. 2007. "CGAP Reflections on the Compartamos Initial Public Offering," CGAP Focus Note No. 42, June 2007.

Farooq, Mohammad, 2008, "The Challenge of Poverty and the Poverty of Islamic Economics" Journal of Islamic Economics, Banking and Finance, 4(2) May-August 2008, .35-58.

Feroz, Ehsan Habib, 2009, "Wrongs to Rights" Islamic Horizons, March/April 2009, pp.2224. [http://papers.ssrn.com/abstract=1409140].

Feroz, Ehsan Habib, 2007, "The Halal Way to Social Change: Is There a Way to Pursue Grameen's Social Agenda without Using Interest?" Islamic Horizons, January/February 2007, p.42. [http://papers.ssrn.com/abstract=1162871].

Grameen Bank. 2006. Past Ten Years at a Glance (2006). Available from: http://www.grameen-info.org/bank/tenyearGBus\$.html\#AtAGlance, accessed December 22, 2007.

Honohan, Patrick. 2004. "Measuring Microfinance Access: Building on Existing CrossCountry Data," Paper prepared for the UNDP, World Bank and IMF Workshop, Data on Access of Poor and Low Income People to Financial Services, October 26, 2004.

IMF. 2005. Sri Lanka: Selected Issues and Statistical Appendix. IMF Country Report No. $05 / 337$. 
IMF. 2007. World Economic Outlook: Globalization and Inequality. IMF World Economic and Financial Surveys, October 2007.

de Mel, Suresh, David J. McKenzie and Christopher Woodruff. 2007a. "Measuring Microenterprise Profits: Don't Ask How the Sausage is Made," World Bank Policy Research Paper No. 4229, May 2007.

de Mel, Suresh, David J. McKenzie and Christopher Woodruff. 2007b. "Returns to Capital in Microenterprises: Evidence from a Field Experiment," World Bank Policy Research Paper No. 4230, May 2007.

de Mel, Suresh, David J. McKenzie and Christopher Woodruff. 2007c. "Who Does Microfinance Fail to Reach? Experimental Evidence on Gender and Microenterprise Returns," Bureau for Research and Economic Analysis of Development (BREAD) Working Paper No. 157, October 2007.

Karnani, Aneel. 2007. "Microfinance misses its mark," Stanford Social Innovation Review, Summer 2007, 34-40.

Khandker, Shahidur R. 2003. "Micro-finance and poverty: evidence using panel data from Bangladesh," World Bank Policy Research Working Paper Series, No. 2945, January 2003.

Morduch, Jonathan and Barbara Haley. 2002. "Analysis of the Effects of Microfinance on Poverty Reduction,” NYU Wagner Working Papers Series, No. 1014, June 2002.

Sri Lanka Department of Census and Statistics. 2001. Brief Analysis of Population and Housing Characteristics. Available from http://www.statistics.gov.lk/PopHouSat/index.asp, accessed December 9, 2007.

Sri Lanka Department of Census and Statistics. 2002. Headcount Index and Population Below Poverty Line by DS Division - Sri Lanka: 2002. Available from http://www.statistics.gov.lk/poverty/index.htm, accessed December 9, 2007.

Sri Lanka Department of Census and Statistics. 2006. Sri Lanka Labour Force Survey Final Report-2006. Available from http://www.statistics.gov.lk/samplesurvey/annual.htm, accessed December 9, 2007.

UNICEF. 1997. Give Us Credit. New York: UNICEF. 


\section{Endnotes}

${ }^{1}$ Dr. Ehsan H. Feroz is a Full Professor of Accounting at the University of Washington, Tacoma, USA. Mr. Goud is currently the Principal of Sharing Risk dot Org who previously served as the Executive Director of IHI. Contact information for Feroz:

ehf2@u.washington.edu, and Goud: blake@ sharingrisk.org. An earlier version of the paper was presented before the $8^{\text {th }}$ Harvard University Forum on Islamic Finance, Cambridge, MA, USA, April 18, 2008. We benefited from the helpful comments of Suvira Chaturvedi, Michael Heyn, Kathy Powers, Brenda Ray Scott, and Christopher Woodruff. Dr. Feroz would like to acknowledge numerous courtesies of Shah Abdul Hannan (former chairman of the Islami Bank Bangladesh Limited), Md. Habibur Rahman (IBBL), Dr. Rezaul (Raj) Karim (UMD), and especially, Mohammad Saeed Rahman, Chairman of the IHI and One Ummah Foundation. Errors are the sole responsibility of the authors.

${ }^{2}$ Although murabaha has a fixed repayment schedule, it is different from conventional microfinance loans because the repayment amount is determined at inception based on the cost of the good financed and the markup charged by the MFI.

${ }^{3}$ Income poverty (receiving income lower than the poverty line) is the most often recognized form of poverty. Other measures of poverty, such as lack of access to affordable healthcare and education, are often thought to be impacted by greater availability of microfinance. Many MFIs provide educational and health-related services on top of the small loans they make to clients.

${ }^{4}$ Many MFIs rely on external funding to provide loans, sometimes because regulations forbid them from accepting deposits. The cost of this funding is usually higher than the interest rates paid to depositors.

${ }^{5}$ The positive spillover effects are increases in income and assets that fellow villagers capture that are not a direct result of having access to microfinance themselves.

${ }^{6}$ A waqf (pl: awqaf) is an Islamic charitable trust where the assets (e.g. land or money) are held in perpetuity by the trust.

${ }^{7}$ The ownership of Compartamos is held mostly by other non-profit organizations that funded its early growth.

${ }^{8}$ A borrower 'strategically' defaults when enforcement of repayment is weak and the borrower has greater benefit from not repaying than continuing repayment when he (she) is able to make repayment.

${ }^{9}$ This procedure can also be used to finance consumption goods, but since our model focuses on creating businesses, we do not explore this application in depth.

${ }^{10}$ The exception to this is a late fee which, if implemented, would correspond to actual costs incurred in collecting repayment.

${ }^{11}$ Another use of microloans is purchasing an asset, like an animal, which can act as a savings vehicle (Boudreaux and Cowen, 2008: 31).

${ }^{12}$ Our description of the microfinance market in Sri Lanka is largely based upon the Consultative Group to Assist the Poor (CGAP) Country-Level Effectiveness and Accountability Review (CLEAR), which interviewed microfinance practitioners throughout Sri Lanka (CGAP 2006).

${ }^{13}$ Based on our assumptions, the nominal (not adjusted for inflation) break-even point is $20.71 \%$ and the adjusted break-even point is $21.79 \%$. However, we believe that our assumptions about repayment rates are very conservative and the realized repayment rates will 
be closer to $90 \%$, at which the unadjusted break even markup is $14.01 \%$ and adjusted breakeven markup becomes $15.02 \%$ 